\title{
Policing a Multicultural Society: A Case for State, Local \& Community Policing in Nigeria
}

\author{
Dr Ganiyu L. EJALONIBU ${ }^{1}$, Ibe C. EZECHI ${ }^{2}$, Dr Muhammad OSOLAFIA ${ }^{3}$, Livinus A. NANDI ${ }^{4}$, \\ \& Lucky A. TONGSI ${ }^{5}$ \\ ${ }^{1,3,4 \& 5}$ Department of Democratic Studies (DDS), National Institute for Legislative and Democratic Studies, National Assembly, \\ Abuja, Nigeria \\ ${ }^{2}$ Department of Economic Development and Social Studies (EDSS), National Institute for Legislative and Democratic Studies, \\ National Assembly, Abuja, Nigeria
}

\begin{abstract}
Nigeria, a multicultural society and a federal state, practices a highly centralized policing system. Over time, this system has not been effective in curbing the incessant security conundrum in the country. Thus, the nation is currently facing several internal security problems and with the inability of the central police command to contain the challenges. So, as a result of the surge in the rate of highly sophisticated crimes in the country, the adoption of state, local and community policing is day-by-day gaining popularity. As such, the major focus of this paper is on the imperatives of state, local and community policing in multicultural Nigerian society. Relying on comparative method and using the lessons learned from crosscountry experiences of some other federal democracies, the paper advocates for the establishment of state, local and community policing as one of the lasting measures to curbing the recurring crimes in Nigeria. This finding showed that by fostering a sense of partnership it is possible to achieve significant impacts in terms of promoting an understanding of cultural diversity among police officers, and overcoming issues which in the past have prevented ethnic minority groups from accessing police services.
\end{abstract}

Keywords: Multicultural Society, Policing, State Police, Local Police and Community Police

\section{INTRODUCTION}

$\mathrm{P}$ olicing as an item in the Exclusive Legislative List that has continued to receive lots of criticisms. In that, over centralization has made the deployment of the police to rapidly address crimes and criminality ineffectual considering the vastness of the Nigerian space and its attendant challenges of diversity occasioned by the large number of ethnic, cultural and religious groups that comprise the country (Egunjobi, 2016). The Nigerian Police (NP) is designated by the 1999 Constitution (as amended) as the national police of Nigeria with exclusive jurisdiction consisting of 37 State Commands (including the FCT) grouped into 12 zones and 7 administrative organs throughout the country (The Nigeria police force, n.d.). As outlined in Section 214 of the 1999 Constitution of the Federal Republic of Nigeria (as amended), the Nigeria Police Force (NPF) is a federal police force; state and local governments are not permitted to establish their own police forces (Immigration and refugee Board of Canada, 2008).
This incongruity is worsened by the fact that many police personnel, who are recruited and deployed to places other than their localities, do not master the environment or communities in which they operate. Such deficit negates intelligence gathering, which is critical to effective policing (The Punch Editorial, 2019). With banditry, robbery, kidnapping, herdsmen killings, cattle rustling and cult-violence at epidemic levels, policing system in Nigeria has become a difficult and challenging task. It should be known that rural communities bear the brunt of most of these shortcomings. While most states in the North are in this hell-hole, their counterparts in the South are engulfed by kidnapping and armed robbery. This confirms the position of the Vice President Yemi Osinbajo that "...policing is a local function; you simply cannot effectively police Nigeria from Abuja" (Koko, 2018: para. 2).

This situation has led to continuous call for the decentralization of the Nigerian Police through constitutional devolution of the powers to establish, organize, maintain and control the police by subnational units making up the Nigerian federation. Based on the above realities, President Muhammadu Buhari commissioned a Presidential Panel on the Reform of the Special Anti-Robbery Squad. The Presidential Panel submitted its report on June $3^{\text {rd }} 2019$, recommending among others, the establishment of state and local government police forces. This is because a centrallycontrolled police cannot provide adequate security to cover a country that is federally structured, as the state police would strengthen security. The aim of this paper therefore, is to advocate for the promotion of state, local and community policing for effective crime control and the maintenance of law and order, manage, and overcome issues of cultural diversity which in the past have militated against policing.

\section{CONCEPTUAL CLARIFICATIONS}

Multicultural Society: The concept of multiculturalism for the first time was introduced in Canada in 1971 in Trudeau administration program (Guo, 2011; Fleras \& Elliott, 2002). Later the United States, Sweden, and Australia adopted the issue in 1975 (Yanık, 2013; Canatan, 2009). It can be viewed as the coexisting of nations coming from different places covering the terms language religion, nationality, culture, 
history and geography (Anık, 2012). The concept of multiculturalism deals with human rights having the same positions, as in modern countries people have to live with each other by different backgrounds, attitudes, traditions, ceremonies with keeping the eyes open to have political balance in social positions which in its own turn leads to power control. Therefore, multiculturalism instead of being seen as the cause of conflicts and challenges can be regarded as the sources of richness and change in the society (Banks, \& Banks, C. 2010; Parekh, 2000).

Presently, there is much more effort toward recognizing the diversity in communities, societies and nations all over the world like informative programs as well as joint business plans. Thus, the concepts and definitions and pros and cons, or simply put it the positive and negative attitudes towards it through the history would make the picture on multiculturalism clearer (Islamic Azad University Tehran North Branch, 2018). Nonetheless, multiculturalism in different parts of the world equally too has different interpretations and definitions. Skin colour, sexual orientation, religious beliefs, previous mistakes and experiences as well as political perspectives constitutes an individual's identity which can lead in to norms and specific definition of the multiculturalism. Likewise in the literature, different definitions can be found which mostly have been because of the different conditions, principles and policies upon the author's usage. Above all, multiculturalism is considered as awareness, understanding and realization of living in interdependent and global society which necessitates people of a certain culture, life style, and religion to understand other people's cultures and comprehend their religious and political systems in order to be effective members of that society.

Moreover, multiculturalism sets people free from narrow communities and guarantees their personal autonomy, equality, and common citizenship and provides collectively shared way of life (Parekh, 1995). While Great number of conservative political commentators like Bloom, (1987); Bullivant, (1981); Glazer, (1975); Hirsch, (1987); Schlesinger, (1992) call it as the triumph of universalism over particularism, Bullivant (1981) referred it as the 'pluralist dilemma'. Furthermore, he explains the pluralist dilemma as 'the problem of reconciling the diverse political claims of constituent groups and individuals in a pluralist society with the claims of the nation-state as a whole. Although Multiculturalism was developed out of cultural pluralism term from its literature yet it is still very difficult to identify the exact time that the word multiculturalism got appeared or even to find out its difference from cultural pluralism. While Gibson (1976), argues that it is ideal towards which social action should be directed, Qi (2011) sees it from the perspective of "humanism" and believes that multiculturalism roots from equal civil rights which can make either positive or negative attitudes on people. This implies that there should be some kind of training programs for people of different cultures on how to get along with each other, how to respect the principles they have which are in some ways specific to them, in order to avoid challenges and conflicts among diverse cultures.

Policing: By simple term policing is referred to the activities carried out by policing actors in order to maintain law and order and provide safety and security (Bakrania \& Haider, 2016). It is used with many different meanings in mind most notably it is referred to as the process of 'ensuring compliance with the law' in all its aspects. ${ }^{1}$ Apparently, ensuring such compliance can never be achieved by the police alone without the people. Moreover, policing indeed encompass more agencies and entities than just the police and is sometimes even taken as a social process involving civil society at large rather than a professional duty carried out by a state agency.

Meanwhile once the word policing is mentioned what comes to the minds of vast majority of people is the activity of state police. However, policing is not just an activity of the state police, it involves any organized activity that seeks to ensure the maintenance of communal order, security and peace through elements of prevention, deterrence, investigation of breaches, and punishment (Baker, 2008). Besides, policing could also be seen a mechanism of governance, which it can be authorized and provided by state and non-state groups/actors. On the other hand, policing is equally an activity carried out by policing actors in order to protect life and property, prevent and detect crime, and preserve and enforce law and order. Accordingly, police are generally regarded as the key security and justice institution that citizens interact with, the main point of entry into the criminal justice system, and the state agency primarily responsible for upholding the rule of law, protecting and promoting human rights, and maintaining public order (SU, 2014). Thus, Efforts to ensure public safety and security require effective state and non-state policing, as well as crime prevention and victim support initiatives.

However, policing and law enforcement are not only the maintenance of law and order only, they include an array of activities in different situations with the predominant ones concerned with the preservation of social order (Muazu, 2012). Perhaps in many societies both developed and developing, several activities have evolved within the context of policing the political and democratic system, the protection of property and with the latest which involves community policing. Nevertheless, in fragile and conflict-affected states, the national police service under the civilian command and control of the Ministry of Interior is often just one actor providing policing to communities. For example, in some African countries, non-state forms of policing undertake key policing roles such as crime prevention and intervention, investigation and resolution, and punishment (Baker, 2008).

https://policehumanrightsresources.org/content/uploads/2016/10/Understandi ng-Policing.pdf?x96812 
State Policing: State police refers to policing in a federal system in which the state government employs police officers for the purpose of policing the state. Aremu (2014:33) describes state policing as "territorial policing. It is a subnational form of policing in which there is devolution of security operations in the hands of the federating states of regions. State policing operationally is when policing and all its operations and logistics are controlled by other governments other than the national or federal government". The recent clamour for a state police force in Nigeria is not empirically unfounded. Nigeria federalism stipulates the devolution of power between the federating units (federal, state and local). Ideally, this must encapsulate powers. The centralized federal police force in Nigeria, have not been able to squarely deal with or respond to the yearnings of citizens for the security of lives and property. Arguably, the central focus of the state police force is to bring the police and effective policing closer to the policed within the state. The state police force is made up of officers who understand the language, geography and the peculiar security challenge of the people they would be policing. Also, as 'insiders' they would work hand in hand with members of the community to provide quality policing service to the people. The constitutional responsibility of the state police force would be to enforce all criminal and crime related laws made by the state legislature and maintain social order within the state.

Indeed, one of the biggest agitations, made louder in recent days, has been for the introduction of state policing. The debate around the issue is partly ideological, but being that Nigeria is not an idealistic nation, the issue is sometimes mistaken for a practical one. On the ideological level, there is the question of Nigeria's federalism (Adekaiyaoja, 2020). Nigeria federalism is by definition a decentralised system, with state executives running 36 individual units. These state executives are kings in their own ways. They control property, budgets, courts and appointments. Yet, control of the police is centralised in Abuja. The major culprit in this issue is Section 214 of the Nigerian Constitution. When interpreted it means that there can only be one Nigerian Police Force, at the federal level. The Inspector General of Police (IGP) heads the Police Force and this IGP is accountable only to one person, the Commander in Chief and President. But that is not what really grinds the gears of the state police agitators. At the state level, each state also has a Commissioner of Police, similar to other functions like Finance, Sports, Health, Water and Justice. But the catch is that these Police Commissioners get appointed by the central government, not the state government; again, the Commissioners of Police take instructions from the IGP in Abuja. Though, sometimes, the Commissioner of Police may receive a directive from a state governor, but they are within their legal rights to demand that the President first approves such orders (Adekaiyaoja, 2020). In essence, state governors can do everything but enforce law and order within their own states.
Paradoxically, part of the justification for this system is the Constitution; it is justified on the basis that it is in the Constitution, and so it should not be amended because it is the Constitution that put this framework in place. However, this constitutional framework is always under attack. One of the most prominent reasons is that the centralised police is incapable of securing Nigerian lives and property. As recently as 2018, the Nigerian Army was deployed in thirty of our thirty-six states, performing functions that ordinarily should be carried out by the police. The argument goes that if it's broken, fix it. Of course, this assumes that state governors will be capable of providing necessary security once the law devolves power to them. And regardless of the level evidence to prove this, the argument persists.

Another popular criticism is control. The recent protests have shown us that the inability of state governors to control the armed government officials within their states makes it difficult to manage the state. They don't control the police because the policemen take orders from Abuja. At least in theory. Put a different way; it is the equivalent of a king having an army in his territory controlled by someone else. Therefore, the argument goes that in a country with state-run police forces, governors would be fully responsible for the actions of the policemen and responsible for their reform. This can satisfy the concerns of some people who cite the positive work that police have done in fighting the Boko Haram insurgency, state authorities can tailor police efforts to unique challenges.

Finally, the third most popular argument is that policing is better done by people from that territory. This is the classic 'son of the soil' debate that policemen in Oyo should be from Oyo. It is easy to challenge. It's a particularly difficult argument to hold because grassroot control in other parts of Nigerian politics has not successfully led to the sort of accountability that is imagined will come about from local policing. Nevertheless, the argument goes that there will be better police-people relations if communities and local governments use their own people. But as always, especially in Nigeria, there's a flip side to these arguments.

How things could turn out on the other foot. For starters, in the hands of an overzealous governor, the police can be a dangerous tool to wield. It can undermine state and federal elections, leave opposition strongholds unprotected and base officers hiring, promotion and dismissal on local politics. On a more alarming level, state police units may become very powerful and begin to take up arms against the federal government. State secessions may even become more viable options if governors build up their fiefdoms. In some cases, governors may turn to warlords, aggressively defending their state territory with the help of the state police. The centre becomes weak. The states break off. When it comes to control, most states will struggle to successfully finance their state police units if they struggle to pay the minimum wage and are so reliant on federal allocation. This risk of underfunding can create very different levels of policing 
across the country. For instance, taxpayers in states like Lagos may better fund their police units, leaving low-income states like Yobe with little to no security. Inequality then widens drastically, creating the risk of poorly policed states that cannot fund their security.

Despite all these arguments, the reality is that the Nigerian police is just a microcosm of the Nigerian state, hampered by inefficiency and still reeling from the sustained legacy of general mismanagement. Police officers are only scarier than most other institutions for one reason, and that is they are licensed to end lives. We know that our police officers receive poor pay, which leads to the often-cited accusations of bribery. A government survey showed police officers are the most likely of all civil servants to seek and take bribes. But that does not justify their failures.

This particular proponent views commentators fear of abuse of the state police by state governors as untenable in the light of the damning allegations of abuse of the Nigerian Police Force (NPF) by those who currently run and control it thereby making it imperative for state police to be established. Similarly, these proponents strongly maintained that doing so will give room for the central command of the police to focus on raising highly professional crop of central squad that may be deployed from time to time when the need arises for special task in the country. Perhaps with the staff present of the police of about 371,800 as against a population of over 200 million Nigerians and judged by the United Nations Standard, the number of available policemen is grossly inadequate as it does not meet the 400 to 1 ratio requirement (Eme \& Anyadike, 2009). Therefore, with a state police structure, the federating units would be able to determine their security needs and raise enough manpower to meet them. Above all in developed nations, the police are trained according to the peculiarities of the localities in which they operate to help fight and reduce crime, perhaps this justifies the reason while the proponents of the police deem it necessary for it to be established.

Furthermore, while for instance the trend of violence and criminality ongoing in the Northern part of Nigeria bothers essentially on terrorism (Boko Haram) especially in the North East, banditry, kidnappings and cattle rustling are predominant in the North West, the South-East and SouthSouth regions grapple with kidnapping essentially to collect ransom from their victims and family, followed with armed robbery, then South-South faced with militancy and pipeline vandalism as their own peculiar security situation while the Southwest Region are known for area boys syndrome, hooliganism, armed robbery and pick pocket. However, those on the other opposing side has punctured the argument for state policing. While in their opinion, creating state police at this stage of the present condition of the country may be an invitation to anarchy and chaos. That apart from the impunity of office and the possibility of abuse of power, state police could lead to the disintegration of the country, especially with the fragile unity in the country at the moment and as some sections of the country feel marginalized in affairs of the country. Also, some other opposing proponents argued that the introduction of state police will worsen the bad security situation in most states of the federation. That is, considering the fate of civil society groups, the community-based organizations, the media and public affairs commentators who are vulnerable in the hands of dare-devil politicians that are easily irritated by fair and objective criticism (James, 2014). This is apart from the fear of governors using state police against political opponents.

Again, the opponents of state police equally based their position on politicians who already use all manner of touts as personal guards to terrorize the common man especially during election period. Even now, the tendency is still very high some over ambitious political leaders may turn the state police to an instrument of a political vendetta. In addition, they argue that state funds will be used to influence a handful of members of the security agencies to intimidate, harass, maim and in extreme cases kill innocent citizens who perform their statutory duties (Egbosiuba, 2013). Besides some may resort to the use of the state security agents to force reporters and journalist to do their biddings. They equally argued on a situation, where Governors can order certain uncompromising members of the House of Assembly around for voicing their dissenting views on an issue which affect the public negatively. Hence it will be better imagined than not, if such governors have powers over the police in the name of state police. Irrespective of the pros and cons of the debates, creation of a State Police structure would also be a major leap in the nation's match towards the much-cherished true federalism that has eluded the nation for a long time, even though the answer might be neither here nor there. Therefore, unless there is a proper reform and adequate checks and balances, state police may end up to become a willing tool in the hands of the overzealous politicians who will use them to achieve their selfish plans.

One of the features of state police is that, it affords the state governors the ability to prevent a breakdown of law and order in their domains by constitutionally equipping them with powers to speedily mandate the police to address and arrest deteriorating conflict situation on time rather than what is obtainable in a federal policing system, where policemen deployed to states deliberately or otherwise show lackluster attitude in swiftly responding to duty calls on the pretext that orders have to be sought from 'above' before action could be taken (Bulus 2012).

Local Policing: Local Police includes municipal, county, tribal, and regional police that derive authority from the local governing body that created it. The primary purpose is to uphold the laws of the jurisdiction, provide patrol, and investigate local crimes (IACP, 2018). Most crimes are local in nature, hence, there is a need for local police formations across Nigeria (Alemika, 2013). This, no doubt, will help to reduce crime rate within the local communities because the local police personnel will be drawn among the people. 
Although some crimes are indeed local, but most major crimes, such as terrorism, trafficking in drugs and human persons, money laundering, armed robbery and burglary are national and international in nature. In some democratic countries, particularly the United States and to a lesser extent in Britain, citizens have traditionally believed that the existence of a national police force would concentrate too much power in the hands of its managers. They have believed that local communities could not hold a national police force accountable for abuses of power, and they have feared that the national government could use such a police force to keep itself in power illegitimately. For those and other reasons, some democratic countries favour organizing police forces on a local basis (Brodeur, in Encyclopædia Britannica, 2021).

Community Policing: Community policing is a commonlyused term but experience shows that it means different things in different contexts. This meaning can further be examined in three dimensions: (a) A set of tactics, often involving some form of community-police dialogue but also including greater levels of patrolling and the establishment of communitypolice liaison officers, designed to strengthen partnerships between communities and police at local levels; (b) A way to strengthen the police's ability to reach into communities, by establishing volunteers at local levels that provide information to the police or act on their behalf, in some cases increasing state control and surveillance; (c) An overarching policing philosophy that recognizes the police must win the trust and support of the public to effectively combat crime and that this implies root and branch reform (National Academies Press, 2018).

On the order hand, community policing can be defined as a collaborative effort between the police and the community that identifies problems of crime and disorder and involves all elements of the community in the search for solution to these problems (Police Executive Research Forum \{PERF\}, 2004). It is based on the assumption that police cannot control crime and disorder alone but require the support of communities to ensure safety. The goals of community policing include: prevention and detection of crime, reduction of fear of crime and improvement of police-community relations. Also, the features of community policing can be presented into three general categories which have been identified as the most common features of police services that have adopted community policing framework. These features, according to Skogan (2006), are achieved through the following efforts:

- Community partnership or engagement: This include discussing priorities and strategies with communities and mobilizing active assistance of the public

- Problem-solving orientation: This focuses on crime prevention rather than crime detection; Studying why people call on the police and trying to tackle underlying causes of problems instead of their symptoms (known as Problem Oriented Policing)

- Organizational transformation and a focus on administrative decentralization: Decentralizing command structures and decision-making, including decisions on expenditure of resources; Developing close cooperation with other parties involved in community safe.

Meanwhile, the essence of community policing is to return to the day when safety and security are participatory in nature and everyone assumes responsibility for the general health of their community not just a selected few, not just the local government administration, not just the safety forces, but absolutely everyone living in the community (Brown, 2001). Furthermore, the concept of community policing has been defined by many scholars and practitioners in various ways. These definitions have assumed categorical styles in order to avoid the risk of generalization. Among these conceptual definitions are the institutional. According to the Office of Community Oriented Policing Service, crime and social disorder is the focus of community policing (Office of community-oriented policing service, US department of justice, 2007). This is achieved through service delivery which includes aspects of regular law enforcement, prevention, problem solving, as well as community engagement and partnership. In order words, community policing model try to strike a balance between reactive responses with proactive-problem solving specifically on the causes of crime and disorder. Thus, community policing is essentially about partnership between the police and the citizens.

Philosophically, community policing represents a drive which aspires to establish partnership between the people and the police in addressing contemporary challenges to security such as social and physical disorder, crime and fear towards achieving overall quality of life (Trojanowicz \& Bucqueroux, 1998). Thus, Community-based policing approaches are seen to be popular due to perceptions that it can build on community initiatives and foster local ownership. However, evidence as to whether such approaches are achieving their objectives remain highly contested. Risks associated with the community policing include the reinforcement of existing inequalities and power imbalances (Denney \& Jenkins, 2013). For instance, evidence from a review of community-based policing in South Africa suggests that such approaches can help increase public confidence in the police, yet there is no evidence that such approaches can reduce crime (Pelser, 2000). Besides, the potential risks of community-based policing suggest more pragmatic approaches to policing assistance. Although Nigeria adopted the language and organizational features of community-based policing in 2005, yet its police force remains politicized, under-resourced, inadequately trained, corrupt and exploitative.

\section{STATE, LOCAL AND COMMUNITY POLICING IN NIGERIA: UNDERSTANDING THE INTRICACIES}

Historically, organized policing was never new to the various communities constituting the present-day Nigeria. For example, among the Yoruba's, the Ilaris, the Emeses, the 
Agurens, etc. enforced native laws and customs, especially the collection of taxes (Rotimi, 2011). In the north, there were Dogaris who served as bodyguard to the emirs (Smith, 1960), but whose duties extend to the capturing and discipline of offenders (Fika quoted in Okemuyiwa, 2012). Later on, the contact of the Yorubas with the colonial police had greatly influenced the way local security men were being organized along that of colonialist. Consequently, the Egba united government established an Egba police on the $27^{\text {th }}$ of July 1905 (Pallinder-Law, 1973). The membership of this police was largely drawn from 'Ode' called native hunters and their original assignment was to combat the menace of armed robbers considered to be on the increase then. Ibadan and many other Yoruba towns subsequently copied the initiatives of the Egbas (Atanda, quoted in Okemuyiwa, 2012). If the evolution of native police among the Yorubas of the southern could be described as an attempt by the Yorubas to copy the colonialists, the British themselves encouraged the evolution of native authority police in the northern Nigeria. Having realized that the institution of emirship was strong in the north, lord Lugard, the governor of northern Nigeria decided to strengthen the existing 'Dogaris'.

Rotimi (2011) identifies four purposes primarily for giving recognition to native police in the north. "These are the need to secure loyalty of the emirs and chiefs, the need to build native administration, the need to reduce cost of administration and lastly, the need to take side with the Hausas in battle for racial superiority with southerners" (Okemuyiwa, 2012: 5). The above name later was changed to native authority in order to allay the fear of domination by non-northerners of the colonial police and eventually, "native authority police in Nigeria was given a colonial recognition by ordinance no 4 of 1916 which not only empowered native authorities to maintain laws and orders in their respective domains, but allowed native authorities to prevent crime and arrest offenders by employing any person to assist them in carrying out their police duties" (Okemuyiwa, 2012: 5). So, with the commencement of ordinance 4, 1916, policing in colonial Nigeria legally became the responsibility of the colonial police and native police, the latter under the management of native authority. This practice was sustained till the independence and survived till few years after. In short, the modern history of policing in Nigeria or what is known today as Nigeria Police Force came into existence in 1861. This is true, as it was done in order to effectively entrench its rule, control the people and resources of the colonized, the British had to create the formal police of 30 men Consular Guard (Agwanwo, 2014).

Nigeria is a federation operating a federal constitution but in practice the country works as a unitary state, a fallout of the centralizing tendencies that have come to characterize the governmental system. It is crystal clear that what is currently practiced in Nigeria is over-concentration of powers at the center as against the philosophy of a true federalism. Federalism presupposes autonomy of each tier of government, which means that both the State and Local governments must be independent of the central government in terms of powers (legislative and judicial), security, finance, appointment, etc. (Nkwede, Dauda \& Orija, 2018). The implications for the decentralization of Police is that the status of Nigerian federal system will begin to take proper shape for effective policing.

Nigeria gained independence from Britain on the $1^{\text {st }}$ October, 1960 and until the termination of the democratic rule by the military on the $18^{\text {th }}$ of January 1966 the politicians of the $1^{\text {st }}$ republic maintained the policing arrangement bequeathed to Nigeria on the eve of independence. For example, although the 1963 constitution established a police force styled Nigeria police force for Nigeria, it permitted regional legislatures to make provision for the maintenance of native police (see Section 105(7) of the Republican Constitution of Nigeria, 1963). Thus, during the first republic, Nigeria as country had both local, regional and central police institutions which was in accordance with the tenets of true federalism. Unfortunately, this arrangement was eroded by the military and replaced with the unitary system which the country's democratic order has adopted over the years. By 1966, following the coup that removed the first civilian administration from office and when General Ironsi took over the mantle of leadership of Nigeria, it had become apparent that native police was a problematic institution.

Consequently, one of the first actions taken by Ironsi military government was to institute a committee to work on the feasibility of the unification of the Nigeria police and local government police and the unification of prisons in Nigeria. Although general Ironsi was no longer alive when the committee submitted its report, General Yakubu Gowon, who took over the mantle of leadership after the assassination of Gen. Ironsi, accepted the recommendation made by the committee that the Nigeria police system be unified. Consequently, native police forces stopped to exist in Nigeria in February 1968 while existing personnel in the several forces were recruited to the Nigeria police force (Ahire, 1993).

\section{POWERS OF STATE GOVERNMENTS OVER INTERNAL/CIVIL SECURITY}

Surprisingly, since 1999 when Nigeria returned to civil and democratic rule, the same single police put in place by military administration has continued to be in operation till today. Up until now, the structure of police in Nigeria negates the concept of State, Local \& Community policing as enshrined in the 1999 Constitution; this is variance to what is obtained in most federal democracies such as United States, Germany, Canada etc. (The Marshall, 2019). Granting controlling rights of police force to sub-national units in Nigerian federation does not contravene the 1999 constitution or any other known law in Nigeria. Rather, it revolves around and seeks to strengthen the following constitutional issues as provided for in the 1999 Constitution of the Federal Republic of Nigeria as amended: 
1. Nigeria shall be a Federation consisting of States and a Federal Capital Territory \{Section 2(2), CFRN\},

2. subnational units should be able to enforce their laws, fight crime and maintain law and order \{see Sections 11(2) and 215(4) of CFRN\},

3. the executive powers to secure a State is vested in the Governor \{Section 5(2) (a) of CFRN\},

4. the Federal Republic of Nigeria shall be a State based on the principles of democracy and social justice \{Section 14 (1) of CFRN\},

5. the security and welfare of the people shall be the primary purpose of government \{Section 14 (1)(b) of. of CFRN\}.

Therefore, based on the above outlined constitutional provisions and in the face of the deploring security situation confronting the nation over a long period of time now, there has been an increased clamor for state, local and community policing. Scholars have argued that a veritable way out of the current security quagmire in Nigeria would be the establishment of state, local and community police formations (Nwogwugwu \& Odedina, 2018; Bakrania, \& Haider, 2016; Agwanwo, 2014; Okemuyiwa, 2012; Ochei, 2001). Accordingly, the proponents of state, local and community police are indirectly canvassing for the decentralization of the force as they believe that it is only such a decentralization of the force as practiced in most advanced countries can rescue the nation from the cliff. Thus, the decentralization of police by allowing state, local and community police to function is supposed to bring the police closer to the community, and may equally succeed in tailoring policing to the specific needs of a community (Bakrania \& Haider, 2016). Besides, each state and local community has its own peculiar security challenges which can only be better managed by the officers who are familiar with the terrain, culture and way of life of a particular people in that given locality.

Thus, in response to the insecurity situation, Governors of the South-West (made up of people of the Yoruba tribe) formed a joint security outfit codenamed, Amotekun (meaning a Leopard). Larry Malemi (in Azubuike, 2021: para 3) gave a detailed account and an opinion on the Amotekun formation. He concludes that: "Amotekun is a masterstroke and the boldest statement any region in Nigeria has ever made to the Federal Government in recent times, devoid of violence or even a public protest. It is a carefully thought protest mechanism against the Government for its inability to tackle insecurity squarely, which have been an infinite continuum. Amotekun is not a cause rather it's a cure. Amotekun is not an ailment rather it is an antidote. Amotekun is not a problem rather it is a solution. Amotekun is not a noise, it is a sound that is understood by a majority of Westerners."

In the South-East (made up of people of predominantly Igbo origin), while the Governors appeared too slow to respond in a similar fashion, the Indigenous People of Biafra (IPOB) formed a security organization known as Eastern Security Network (ESN). From the reports, South-Eastern Governors had since distanced themselves from ESN. After protracted effort, the Governors of the South-East has now formed the region's security outfit known as Ebube Agu, which literally means, "Glory of a Leopard" (Azubuike, 2021).

Early in 2020, a group (Coalition of Northern Groups) in the Northern part of Nigeria formed a regional security organization known as Shege Ka Fasa for the purpose of tackling kidnapping and banditry in the region. Shege Ka Fasa is an Hausa expression which means "I dare you". Beyond the clamour for security, a close observation of the turnout of events would reveal that Nigeria is currently terribly divided along ethnic lines. There is so much bloodshed fueled by animosity and lack of peaceful coexistence (Azubuike, 2021).

From Amotekun to Ebube Agu, Southerners have now turned to "Leopards" for their security. It remains to be seen how well these formations will wade off kidnappers, robbers, bandits and other killers terrorising the regions. Although the North appears to be in control of the national security agencies, Northerners equally feel insecure. Reports from Borno, Zamfara, Kaduna and other areas are sickening (Adebayo, \& Okoyomoh, 2010). Therefore, the proponents of State and Local policing validate their position with the general constitutional duty of government to ensure that security and welfare of citizens are the primary purpose of government under Section 14(2)(b) CFRN 1999. Other proponents argue that a civilian security outfit with emphasis on intelligence gathering is valid under Section 24(e) of the CFRN 1999 where the duty of every citizen is to render assistance to appropriate and lawful agencies in the maintenance of law and order.

However, the antagonists have countered this opinion that provisions of the Constitutions cannot be read in isolation because the law requires a section of a statute to be construed as part of a greater whole. Consequently, they argued that the legislative powers of the States and Federal Government are delimited under the legislative lists contained in Second Schedule in which Item 45 of the Exclusive Legislative List places the powers over police and other government security services established by law within the legislative competence of the Federal Government (Adebayo, \& Okoyomoh, 2020). Therefore, only the Federal Government, to the exclusion of State or Local Government, may legislate or make policies on matters related to policing or other government security services. Accordingly, some people believe that if Operation Amotekun, Ebube Agu and Shege Ka Fasa were set up as police formations or conventional security agencie, then the State governors have acted beyond their constitutional powers.

Also, by Section 227 of the Constitution: "no association shall retrain, organize, train or equip any person or group of persons for the purpose of enabling them to be employed for the use or display of physical force or coercion in promoting any political objective or interest or in such a manner as to arouse reasonable apprehension that they are organized and 
trained or equipped for that purpose. Available facts are that Operation Amotekun was initiated by the Development Agenda for Western Nigeria (DAWN) Commission a largely political organization, and an offshoot of the Odu'a Investment Company Limited; just like IPOB is suspected to have formed Eastern Security Network (ESN). Another constitutional issue is the geographical spread of Operation Amotekun, Ebube Agu/Eastern Security Network and Shege Ka Fasa described as a security formation for regions. It should be underscored that Nigeria has long abandoned regionalism and the CFRN 1999 does not recognize these Regions as political entities capable of making laws or enacting executive policies. The constitution does not provide for a regional political structure, rather, it recognizes states and vests them with the requisite political structures to make laws and implement policies (Adebayo, \& Okoyomoh, 2020).

It is however noteworthy to mention here that A bill seeking to give legal backing to state security outfits has passed second reading at the Nigerian House of Representatives (Akpan, 2021). The constitution alteration Bill, sponsored by Hon. Oberuakpefe Afe (PDP- Sapele/Uvwie/ Okpe Federal Constituency, provides for the establishment of a state security service commission to regulate the operations of security outfits sponsored by the states. This means that organisations such as Amotekun in the Southwest, and Ebube $\mathrm{Agu}$ in the Southeast, will be officially recognised by the constitution if the bill is passed into law.

\section{POLICING AND CROSS-COUNTRY EXPERIENCES}

The character of a society, to a large extent, influences the organization, function and performance of the police. The conduct and nature of police activities in any society will be a pointer to the character of the political regime in that society. No government will be seen to be democratic, if the policing power is over centralized; this is true as police power can be used to restrict meetings of perceived opposition states, or intimidate the government of a subnational unit (state) by use of force. Today, in most of the western world, the policing powers are exercised at virtually every level of government (Van Maanen \& Barley, 1984). Therefore, the rest of this segment is dedicated to the analysis of policing power and its exercise in Canada, Germany, USA, Australia and France for us to take relevant lessons from them.

Canada: Being a Commonwealth country, Canada has adopted a community-based policing strategy that has more in common with its British and Australian counterparts than with American policing tactics, especially when it comes to large cities.

Germany: Policing has always been a responsibility of the states in Germany but of course with the exception of Nazi era when state police forces were unified under central control and a national police force was created (Reichssicherheitshauptamt or RSHA) (German Federal Ministry of the Interior, 2019). However, in light of the gross misuse of power by the centralized Nazi state, the new West
German constitution provided a strict separation of powers, placing law enforcement firmly in the hands of the states (German Federal Ministry of the Interior, 2019). The only policing agencies allowed at the federal level were the paramilitary Federal Border Guard (German: Bundesgrenzschutz), also responsible for coast guard services and the Federal Criminal Police, both under the supervision of the Federal Ministry of the Interior (German Federal Ministry of the Interior, 2019). Thus, the federal structure of the Federal Republic of Germany gives the states (Länder) the authority to maintain their own police forces within their territory, along with the right to pass legislation and exercise police authority (German Federal Ministry of the Interior, 2019). Due to this division of authority, Germany has 16 state police forces and three federal law enforcement agencies, one of which is the Federal Police. The Federal Police is a specialized force responsible for border protection, railway policing and aviation security. Because Germany's borders became largely open since 2005 , due to the development of the European Union and the Schengen Agreement to all neighborhood countries, the Bundesgrenzschutz was renamed to Federal Police (German: Bundespolizei). It is important to note that the duties of the Federal Police still are limited to the security of railway lines, main railway stations, airports, sea ports, and several other special duties (German Federal Ministry of the Interior, 2019).

United States of America: In the United States of America (USA) police service is divided into about 40,000 separate agencies with no national governmental control, support or inspection, and often with more than one agency having jurisdiction in one place (Bunyard, 1978). Normal police functions are carried out by a mixture of police forces based on states, counties, townships and villages formations. The appointments of heads of police departments are dependent on local government elections. In the U.S., police officers can be Marshals, Sheriffs or Constable, and in any one town it is possible to find the State Police, the county Sheriff's office, the City Police Department and even the Federal Bureau of Investigation (FBI), and all of them with some form of jurisdiction (Egunjobi, 2016). Other types of police formations coexist with the Federal Bureau of Investigation, which focuses on more than 200 classes of offences. Just as 12,236 municipal police formations exist, so are those of universities and colleges. Apparently, there is no way the FBI, even with its high level of efficiency, can alone perform the job of different law enforcement agencies at various levels. The biggest difference between American and Nigerian police is that Nigerian police enforce a single federal police Act, whereas in the United States different states have their own police force, which in many cases differs from the Nigerian federal case.

Australia: Australia is another country with federal political structures that has federal police force as well as state forces. The State police in Australia operates on the same principles as those observed in the United States. In Australia, for 
example, each of the six states has its own police force and its own laws but does not legislate in matters pertaining to federal organizations and cannot pass laws at variance with those of the commonwealth (Bunyard, 1978).

France: In France, the country is divided into departments and each headed by prefect, who owes his appointment to the central government, but is responsible for law and order. In that, two national organizations carry out policing duties in the country - the Police Nationale, with authority over the entire country, but restricted to towns with up to 10,000 people, and the Gendarmerie who police rural areas and town of less than 10,000 inhabitants (Encyclopedia Britannica, n.d). The Police Natioinale and Gendarmerie co-existence is due to historical accident, but effort to unify them has been abortive, because the dual system prevents the whole county's formation from coming under one operational command. However, since the members of the two formations are clearly instruments of one government, it seems that the safeguard is purely notional (Encyclopedia Britannica, n.d).

\section{IMPERATIVES FOR STATE, LOCAL \& COMMUNITY POLICING IN NIGERIA}

The importance for the existence of state police in a federation cannot be overemphasized. First off, having just a single national policing outfit is at complete variance with a federal system of government (Obakhedo (2015). This is so because, one of the pertinent principles of federalism is the division of power between the central and regional (sub-national) governments in order to preserve the independence of both tiers of government in the performance of their respective duties (Ubani (2005). It is on this basis that Falana (2015) submitted that, the issue of establishing state police is necessary in a federation. The central focus of the state police force would be to bring the police and effective policing closer to the policed within the state. The state police force is made up of officers who understand the language, geography and the peculiar security challenge of the people they would be policing, thereby, making them 'insiders' who would work hand in hand with members of the community to provide quality policing service to the people (Agwanwo, 2014).

Basically, community policing is a philosophy with operating principles based on the assumption that changes today will make communities safer and more attractive tomorrow, which is achieved by working together towards shared goals (Segrave, \& Ratcliff, 2004). Besides, community policing brings the police and community closer and offers a myriad of other benefits. For instance, Palmitto explains the benefit of community policing to be a game the Police can't lose. That is if collaboration through community participation leads to lower crime rates and higher arrest rates, the police can take the credit for being foresighted agents of change. Again, if community policing fails to increase public security, the public is hardly likely to reduce support for policing because a new gambit doesn't work out. Moreover, even if the police cannot actually deliver on the large goal of crime reduction, a heightened police presence is reassuring. Thus, community policing reduces fear of crime and from the perspective of political benefits to police, delivers the message that police care (Palmiotto, 2000).

In specific terms, Coqilhat (2008) identifies some imperatives for community policing to include the following:

- Improving police-community relationships and community perceptions of police;

- Increasing community capacity to deal with issues;

- Changing police officers' attitudes and behaviours;

- Increasing perceptions of safety; and

- Reducing crime, disorder and anti-social behavior

However, the major problem with the Nigerian Police Force being that they are too removed from the people, thus the relationships between them and the local communities are virtually non-existent. For instance, majority of people have argued that the Boko Haram insurgence which has being prolonged is because the police in its present form are inhibited by some factors that make victory difficult. Majority of the policemen in Borno state are non-indigenes who do not know the terrain and thus cannot be effective for intelligence gathering without blowing their cover. Therefore, crime detection, prevention and citizen protection need a broader knowledge which only local policing can better provide as it will be constituted of indigenes with a good knowledge of the community and terrain which is very critical for effectiveness and efficient service delivery to their mandate.

Most people willingly obey most laws, whether a police officer is present or not. They comply with the laws because they consider them fair and because they believe that in the long run it is in their interest to observe them. In small communities in which most citizens know each other, people who live up to the community's shared ideals are rewarded with the esteem of their fellow citizens. If they break the law or fall short of other people's expectations, their lives often become more difficult because they are shamed, shunned, or ostracized by the rest of the community and are less likely to receive assistance in times of trouble (Aspilos Foundations, 2020). In all societies this system of informal rewards and punishments is the most potent aid to law enforcement, but it is strongest in small communities. The forces that order life in a small community thus make the task of the police much easier. Police action is needed only when such informal controls have proved insufficient.

This is why rural and sparsely populated areas are often policed by a single centralized - and often militarized-police force, even in countries that have a decentralized police system. A single police organization operating under a unified command is more cost-effective and more operationally efficient than a bevy of independent small-town police forces. Since the territory to cover may be very large and characterized by difficult terrain, police in such regions must have the long-range mobility and adaptability that are characteristic of military forces (Ibid, 2020). In addition, the 
countryside has historically been policed by military organizations, as police forces were initially created in urban settings. (The great exceptions to this model are the United Kingdom and the United States, which have long resisted police centralization).

\section{ADVANTAGES OF STATE, LOCAL \& COMMUNITY POLICING}

Our analysis has shown that there are lot of advantages state, local and community policing which can be identified as follows:

1. True Federalism: The logic of federalism requires that subnational units should be able to enforce their laws, fight crime and maintain law and order.

2. Quick response to security challenges: It will aid deployment of the police to rapidly address crimes;

3. Removal of the contradictory provisions in the 1999 Constitution: The 1999 Constitution (as amended) for instance, in Section 11(2) empowers State House of Assembly to make laws with respect to the maintenance and securing of public safety and public order in their States. And it is in line with this that Section 215(4) of the Constitution states that: Subject to the provision of this section the Governor of a state... may give the Commissioner of Police of that state such lawful directions with respect to the maintenance and securing of public safety and public order as he may consider necessary, and the Commissioner of the Police shall comply.... The contradiction, though, is that while assigning the State Government a role in the maintenance of public safety and public order, the constitution proceeds to deny them independent capacity for discharging these functions, when Section 214(4) carries a provision which stipulates that before carrying out any such directive of the Governor. ...the Commissioner of Police may request that the matter be referred to the President or such Minister of the Government of the Federation as may be authorized in that behalf by the President for these directions...;

4. Once the policing power is devolved, it will be an opening gate for other issues requiring devolution; for example, it will reduce monopolistic control of federal Police to impose its political preferences upon the State.

\section{LIMITATIONS AND MAIN CRITICISMS AGAINST THE STATE, LOCAL \& COMMUNITY POLICING}

1. Most non supporters of State, Local and Community Policing have argued that state police would be a veritable tool of vendetta in the hands of some politicians, especially the governors, who would statutorily be in charge of them as the chief security officers of their states, in line with the 1999 Constitution as amended. Thus, if states and local government authority are allowed to own their police forces, it would be used to perpetuate themselves in office at all cost to the detriment of the electorate who may want to change an unpopular and underperformed government. This was experienced when the country practiced Regional and Local Government Police system shortly after independence. However, the non-supporters of state police are reminded of the multiple police structures in the United States and other federations that work seamlessly with strict legislative checks and balances.

2. Oppression and intimidation: It is also feared that the establishment of state police would further increase the use of the police as an instrument of oppression as the ruling class and their friends will use it to intimidate and harass the public especially armless civilians.

3. Funding: One other criticism is the issue of the capacity to fund a local or community police service. So, funding of the State, Local and Community police has often been an issue especially with dwindling revenue to governments. According to a report prepared by BudgiT (2019) about thirty-three state governments cannot finance their recurrent expenditure without federal allocation. In fact, many States are presently unable to implement new minimum wage of Thirty Thousand (N30,000.00) Naira, citing paucity of funds as their reason, yet security votes to governors still runs into billions of naira and which is largely unaccounted for.

\section{CONCLUSION AND RECOMMENDATIONS}

Police are well-known as state institutions, operating under national authority and within national sovereignty. For many, police are the most visible representatives of the state. They can operate in a centralized or decentralized system, organized at a federal, state or provincial level, divided into a judicial or a uniformed agency. Against the backdrop of Nigeria's current huge security challenges one veritable way out of the quagmire of insecurity and similar challenges would be the establishment of State, Local and Community Police Forces. This submission is borne out of the persistent allegations of ineffectiveness and abuse of the Nigeria Police (NP) by those who currently run and control it. Furthermore, formation of State, Local and Community Police forces would be more penetrable and widespread as well as more community friendly relative to the current centralized Police structure. In addition, since State Governments now bear a reasonable percentage of the platforms and other logistics elements for securing their various states, it would only make sense for them to be constitutionally empowered to establish, fund and operate the state police. In the light of the above, the following measures are recommended:

1. The 1999 Constitution should be amended to clearly define the jurisdictions of both Federal and State Police 
Forces as well as local and community police; so that there wouldn't be conflict of interest with respect to areas of jurisdictions. For example, Section 21(1) which gives the National Assembly power to make laws for the Federal Police should be amended to give both State Assemblies and Local Councils powers of their jurisdictions.

2. Section 214 sub section 1 of the 1999 Constitution which says that "and subject to the provisions of this section, no other police force shall be established for the Federation or any part thereof', should be amended. This would address one of the issues that is generating serious debate in Nigerian federalism (i.e. removing policing from the Exclusive Legislative List).

3. Each State in the country should be empowered to establish its police force which will be organized and administered in accordance with such provisions as may be prescribed by a law of the State House of Assembly.

4. Lessons drawn from the cross-country examination shows that the state, local \& community policing of some federal states such as Germany, United State of America, Australia, and France are most appropriate for adaptation in Nigeria.

5. Once policing power is devolved, it will be imperative to review the present revenue sharing formula so as to provide more revenues for the states to shoulder the new responsibility. Under the extant formula, the Federal Government collects 52.68 per cent; states 26.72 per cent and Local Government Areas 20.60 per cent.

\section{REFERENCES}

[1] Adebayo, T. \& Okoyomoh, P. (2020). Operation Amotekun - is it valid under Nigerian Constitution? Accessed from https://www.topeadebayollp.com/insights/display/13/OPERATION -AMOTEKUN -\%E2\%80\%93-IS-IT-VALID-UNDER-NIGERIANCONSTITUTION?

[2] Adekaiyaoja, A. (2020). The state vs federal debate for policing in Nigeria. Available at https://www. stearsng.com/article/the-state$v$ s-federal-debate-for-policing-in-nigeria

[3] Agwanwo, D. E. (2014). State Policing and Police Efficiency in Nigeria. Journal of Research on Humanities and Social Sciences, 4(25): $165-173$

[4] Ahire P.T. (1993). Native Authority Police in Nothern Nigeria: End of An Era, in T.N Tamuwo, I.L. Bashir, E.E.O. Alemika and A.O. Akano ed, Policing Nigeria: Past, Present and Future. Lagos: Nigeria Police Force and Malthouse Press Ltd.

[5] Akpan, S. (2021). Amotekun, Ebube Agu to get legal backing as reps consider state security bill. https://www.thecable.ng/amotekun-ebube-agu-to-get-legalbacking-as-reps-consider-state-security-bill

[6] Alemika, E. E. O. (2013). The impact of organised crime on governance in West Africa. Friedrich-Ebert-Stiftung.

[7] Anık, M. (2012). Kimlik ve çokkültürlülük sosyolojisi [Identity and sociology of multiculturalism]. Aç1lım Kitap.

[8] Atanda, The New Oyo Empire, Page 85-98.

[9] Azubuike, S. (2021). From Amotekun to Ebube Agu: Why Southerners turned to Leopards for their security. Accessed from https://stephenlegal.ng/from-amotekun-to-ebube-agu-whysoutherners-turned-to-leopards-for-their-security/

[10] Baker, B. (2008). Multi-Choice Policing Stockholm: ElandersGotab AB
[11] Bakrania, S. with H. Haider (2016). Safety, Security and Justice: Topic Guide. Birmingham, UK: GSDRC, University of Birmingham.

[12] Bakrania, S. with H. Haider (2016). Safety, security and justice: Topic guide. Birmingham, UK: GSDRC, University of Birmingham

[13] Banks, J., \& Banks, C. (2010). Multicultural education: Issues and perspectives (7th ed.). Wiley.

[14] Bloom, A. (1987). The Closing of the American Mind: how higher education has failed democracy and impoverished the souls of today's students. New York: Simon and Schuster.

[15] Brodeur, J. P. in Encyclopædia Britannica, Inc. (2021) Police. Retrieved from https://www. britannica.com/topic/police on 10th Feb., 2021.

[16] Brown, J. (2001). "Community Policing Reality Check." Law and Order, April 2001, pp. 55-58

[17] Bullivant, B. (1981). The Pluralist Dilemma in Education: six case studies. Sydney: Allen and Unwin.

[18] Bunyard, R. S. (1978). Police: organization and command. Plymouth: MacDonald and Evans.

[19] Canatan, K. (2009). Avrupa toplumlarında çokkültürlülük: sosyolojik bir yaklaşım [Multiculturalism in Europea societies: A sociological

[20] Coqilhat, J. (2008). Community Policing: An International Literature Review. Wellington: New Zealand police

[21] Denney, L., \& Jenkins, S. (2013). Securing communities: The what and the how of community policing. ODI. Retrieved from http://www.odi.org.uk/sites/odi.org.uk/files/odi-assets/ publications-opinion-files/8491.pdf on $10^{\text {th }} \mathrm{Feb} ., 2021$

[22] Denney, L., \& Jenkins, S. (2013). Securing communities: The what and the how of community policing. London: ODI. http://www.odi.org.uk/sites/odi.org.uk/files/odiassets/publications-opinion-files/8491.pdf

[23] Egbosiuba M. (2013). Decentralization of Nigerian Police Force, Blog, All Things Nigeria.htm

[24] Egunjobi, A.A. (2016). The Nigerian Federal Practice and the Call for State Police. International Journal of Advanced Academic Research, Social \& Management Sciences, Vol. 2, Issue 7 Pp. 114

[25] Eme, O. I. Anyadike, N. O. (2009). Security Challenges and the Imperatives of State Police

[26] Encyclopedia Britannica, Decentralized police organizations. Available @ https://www.britannica.com/topic/ police/Decentralized-police-organizations

[27] Fleras, A., \& Elliott, J. L. (2002). Engaging diversity: Multiculturalism in Canada (2nd ed.). Nelson Thomson Learning

[28] German Federal Ministry of the Interior (2021). Law enforcement in Germany. Retrieved from https:// www.bmi.bund. de/EN/topics/security/federal-policelfederal-police-node.html on $10^{\text {th }}$ Feb., 2021

[29] German Federal Ministry of the Interior. Law enforcement in Germany. Retrieved from https://www.bmi.bund. $\mathrm{de} / \mathrm{EN} /$ topics/security/federal-police/federal-police-node.html on 10th Feb., 2021.

[30] Germany Federal security agencies- Retrieved from http://themarshall.wikia.com/ wiki/Law_enforcement_in_Germany on 10th Feb., 2021.

[31] Gibson, M. A. (1976). Approaches to multicultural education in the United States: Some concepts and assumptions. Anthropology and Education Quarterly, 7, 7-18.

[32] Glazer, N. (1975). Affirmative Discrimination: ethnic inequality and public policy. New York: Basic Books.

[33] Guo, Y. (2011). Perspectives of immigrant Muslim parents: Advocating for religious diversity in Canadian schools. Multicultural Education.

[34] Hirsch, E. (1987). Cultural Literacy: what every American needs to know. Boston: Houghton Mifflin

[35] IACP (2018). Types of Law Enforcement Agencies. Retrieved from https://www.discoverpolicing. org/explore-the-field/types-oflaw-enforcement-agencies/ 
[36] Immigration and refugee Board of Canada (2008). Responses to information requests (RIRs). Retrieved from https://www.justice.gov/sites/default/files/eoir/legacy/2013/12/18/ NGA 102889.E.pdf on 10th Feb., 2021.

[37] In the United States for example, there are federal, states, county and municipal Police. Retrieved from http://www.drtomoconnor.com/megapolice.htm on 10th Feb., 2021.

[38] Islamic Azad University Tehran North Branch (2018)

[39] James, U. (2014). Can State Police Solve Nigeria's Security Problem? Nigeria News World Magazine.htm, Thursday, 19th June, 2014

[40] Koko, (2018). Osinbajo: You Simply Cannot Effectively Police Nigeria From Abuja, We Need State Police. Retrieved from https://koko.ng/osinbajo-you-simply-cannot-effectively-policenigeria-from-abuja-we-need-state-policel on 10th Feb., 2021.

[41] Muazu, B (2012), The Search for National Security In Nigeria: challenges and prospects www.nigerstate.gov.ng/../ the-searchfornational-security-in-nigeria-cha. on $10^{\text {th }}$ Feb., 2021

[42] Nkwede, J.O., Dauda, K.O., \& Orija, A.O. (2018). Federalism and Contending Issues in Contemporary Nigeria: Mapping alternative perspectives for a neo-federalist paradigm. Asian Social Science, 14 (10): 111-119

[43] Nkwede, J.O., Dauda, K.O., \& Orija, A.O. (2018). Federalism and Contending Issues in Contemporary Nigeria: Mapping alternative perspectives for a neo-federalist paradigm. Asian Social Science, 14 (10): 111-119.

[44] NPC (2021). History of the Nigeria police force. Retrieved from https://www.npf.gov.ng/aboutus/ History_Nigeria_Police.php on $23^{\text {rd }}$ January, 2021

[45] Nwogwugwu, N. \& Odedina, A. M. (2018). Policy Framework for Community and State Policing in Combating Rising Security Challenges in Nigeria. International Relations and Diplomacy, 6(6): 334-345. doi: 10.17265/2328-2134/2018.06.003

[46] Ochei, O. (2001). Democratization and the Management of African Security" in Akindele, R. and Ate, B (eds) in Nigerian Journal of International Affairs, vol.13, No.1, Lagos, NIIA.

[47] Office of community oriented policing service, US department of justice (2007). What is community policing? Retrieved from http://www.cops.usdoj.gov/default\%20asp?item $=36$ on $10^{\text {th }}$ Feb., 2021

[48] Okemuyiwa A.A, (2012). State Police in Nigeria: \{Issues and Challenges $\}$. Available at: $h t t p: / / s s r n . c o m / a b s t r a c t=2088033$

[49] Oliver W. M., (ed) 2000. Community policing: Classical readings, New Jersey, Prentice-Hall.

[50] Pallinder-Law. A. (1973). Government in Abeokuta 1830-1914 with special reference to the Egba United Government 1898-1914' Ph.d Thesis, University of Gothenburg, 1973, 114.

[51] Palmiotto, M. (2000), Community Policing: A Policing Strategy for 21st Century, Aspen Books

[52] Parekh, B. (1995). Introduction. New Community 21, 147-151.

[53] Parekh, B. (2000). Rethinking multiculturalism: Cultural diversity and political theory. Palgrave.

[54] Pelser, E. (2000). An overview of community policing in South Africa. In I. Clegg, R. Hunt \& J. Whetton. Policy guidance on support to policing in developing countries. Swansea: University of Wales. Retrieved from http://www.gsdrc.org/docs/open/SEC4.pdf on $10^{\text {th }}$ Feb., 2021

[55] Pelser, E. (2000). An overview of community policing in South Africa. In I. Clegg, R. Hunt \& J. Whetton. Policy guidance on support to policing in developing countries. Swansea: University of Wales. http://www.gsdrc.org/docs/open/SEC4.pdf

[56] Police Executive Research Forum (PERF) (2004). Community Policing, the past, present and future, 2004. Retrieved from www.policeforum.org on $10^{\text {th }}$ Feb., 2021

[57] Qi, J. (2011). Diversity and multiculturalism in Japan: What is called into question? Educational Research for Policy and Practice,10, 105- 114. http://dx.doi.org/10.1007/s10671-0109097-y.

[58] Rotimi, K. (2011). The Police in a Federal State. The Nigerian Experience. College Press Ltd. P 1.
[59] Schlesinger, A. (1992). The Disuniting of America: reflections on a multicultural society. New York: W.W. Norton and Co.

[60] Section 14 (1) of the Constitution of the Federal Republic of Nigeria

[61] Section 14 (1)(b) of the Constitution of the Federal Republic of Nigeria

[62] Section 2(2) of the Constitution of the Federal Republic of Nigeria

[63] Section 5(2) (a) of the Constitution of the Federal Republic of Nigeria

[64] Segrave, M. and Ratcliff, J. (2004) Community Policing: A Descriptive Overview

[65] Segrave, M. and Ratcliff, J. (2004) Community Policing: A Descriptive Overview

[66] Skogan, W. G. (2006). Police and Community in Chicago: A Tale of Three Cities. New York: Oxford University Press.

[67] Smith, M.G, (1960). Government in Zuzzau, 1880-1950. London, Oxford University Press.

[68] SU. (2014). Policing the context: Principles and guidance to inform international policing assistance. Stabilisation Unit. http://sclr.stabilisationunit.gov.uk/top-10reads/thematic/securityand-justice-general/policing/441-policingthe-context-principles-and-guidance-to-informinternationalpolicing-assistance?path=security-and-justice-general/policing

[69] The Marshall (2019). Germany Federal security agencies. Retrieved from http://themarshall.wikia. com/wiki/Law_enforcement_in_Germany accessed on $1^{\text {st }}$ July, 2021.

[70] The Punch Editorial (2019). Buhari's faulty stand on state police. Accessed@https://punchng.com/buharis-faulty-stand-on-statepolicel on $23^{\text {rd }}$ January, 2021

[71] Tiedke K. \& W. Freeman C. Sower J. Holland, (1957). Community involvement. Glencoe, IL: The Free Press.

[72] Trojanowicz R. \& Bucqueroux, B. (1998). Community policing: how to get started, 2nd edition, Cincinnati: Alderson publishing co.

[73] Van Maanen, S. \& Barley, D. (1984). Toward a richer understanding of police culture. Retrieved from http://www.policeadmin.wiki.uml.edu ) on $10^{\text {th }}$ Feb., 2021

[74] Van Maanen, S. \& Barley, D. (1984). Toward a richer understanding of police culture. Retrieved from http://www.policeadmin.wiki.uml.edu on 10th Feb., 2021.

[75] Wong K. C., 2008. A General Theory of Community Policing. Ohio. Retrieved from http://works.bepress.com/kam_wong/6. on 10th Feb., 2021.

[76] Yanık, C. (2013). Dünyada ve Türkiye'de çokkültürlülük [Multiculturalism in the world and Turkey]. Sentez Yayıncılık.anoth, L. Saini. 